\title{
Performance and emissions of a single cylinder diesel engine operating with rapeseed oil and JP-8 fuel blends
}

\begin{abstract}
The article presents experimental test results of a DI single-cylinder, air-cooled diesel engine FL 511 operating with the normal (class 2) diesel fuel (DF), rapeseed oil (RO) and its 10\%, 20\% and 30\% (v/v) blends with aviation-turbine fuel $J P-8$ (NATO code F-34). The purpose of the research was to analyse the effects of using various rapeseed oil and jet fuel RO90, RO80 and RO70 blends on brake specific fuel consumption, brake thermal efficiency, emissions and smoke of the exhaust. The test results of engine operation with various rapeseed oil and jet fuel blends compared with the respective parameters obtained when operating with neat rapeseed oil and those a straight diesel develops at full (100\%) engine load and maximum brake torque speed of $2000 \mathrm{rpm}$.

The research results showed that jet fuel added to rapeseed oil allows to decrease the value of kinematic viscosity making such blends suitable for the diesel engines. Using of rapeseed oil and jet fuel blends proved themselves as an effective measure to maintain fuel-efficient performance of a DI diesel engine. The brake specific fuel consumption decreased by about $6.1 \%(313.4 \mathrm{~g} / \mathrm{kW} \cdot \mathrm{h})$ and brake thermal efficiency increase by nearly 1.0\% (0.296) compared with the respective values a fully (100\%) loaded engine fuelled with pure RO at the same test conditions. The maximum NO emission was up to $13.7 \%$ higher, but the CO emissions and smoke opacity of the exhaust $50.0 \%$ and $3.4 \%$ lower, respectively, for the engine powered with biofuel blend RO70 compared with those values produced by the combustion of neat rapeseed oil at full (100\%) engine load and speed of $2000 \mathrm{rpm}$.
\end{abstract}

Key words: diesel engine, rapeseed oil, JP-8 fuel, engine performance, exhaust emissions

\section{Introductiong}

The EU Directive 2009/28/EC approves a target of a $20 \%$ share of renewable biofuels in overall transport petrol and diesel consumption by 2020 to be introduced in a cost-effective way. Rapeseed oil methyl ester (biodiesel) is widely used for diesel engines powering as alternative energy source to replace traditional diesel fuel. Renewable and popular in Europe rapeseed oil (RO) is also commonly used for local tractor powering to alleviate fuel shortage problems and diminish the ambient air pollution due to closed-cycle $\mathrm{CO}_{2}$ circulation. Many researchers around the world provide analyses of potential advantages and disadvantages to be gained by the use of crude rapeseed oil in compression ignition engines [1-4].

Despite many chemical and physical properties of RO are more or less similar with those of diesel fuel (Table 1), however some differences have essential impact on fuel injection, atomisation, the air and fuel mixing rate in the cylinder, combustion process and thus emissions of the harmful exhaust gases [5]. At first, one of the main problems related with using of pure rapeseed oil in a diesel engine is connected with more than 10 times higher kinematic viscosity of rapeseed oil as compared with the normal diesel fuel $[6,7]$. In order to use more viscous crude rapeseed oil for diesel engine powering must be solved problem related with its worse flow through long pipes of a small diameter in the fuelling system, filtration in fine porous filter elements, atomisation and distribution of the oil portion injected across the combustion chamber volume and slow evaporation of RO droplets $[8,9]$.

One of possible methods to reduce the viscosity of crude vegetable oil of various origin is its mixing with traditional diesel fuel and lighter mineral fuels $[10,11]$. Aviation turbine fuel JP-8 is military kerosene based turbine type (NATO code F-34) fuel produced from civil fuel Jet A-1 and widely used by the Air Force of USA army and in Europe. Aviation turbine JP-8 fuel is produced at the oil refinery plant "Orlen Lietuva" (Mažeikiai) and its quality parameters satisfy the MIL-DTL-83133E specifications (AVTUR/FSII). The JP-8 fuel is almost exclusively extracted from the kerosene fraction of crude oil, the distillation points of which are between the gasoline fraction and the diesel fraction [12]. The composition of jet fuel includes a small amount of anti-icing of fuelling system inhibitor S-1745, i.e. an additive, which deepens a freezing temperature of JP-8 fuel at high altitudes to avoid build-up of ice crystals in the fuelling system, and lubricity improving additive S-1747 [13]. Using of this alternative fuel as a lighter additive to prepare jet-rapeseed oil fuel blends should significantly reduce density and kinematic viscosity, improve cold filter plugging point, filtration properties and vaporisation quality of the tested rapeseed oil and jet fuel blends. A bit lower carbon-to-hydrogen ratio and thus higher net heating value of JP-8 fuel may contribute to better performance efficiency of a diesel engine with these alternative fuel blends.

However, the cetane number of turbine type JP- 8 fuel is lower (42.3) than that (44-48) of crude rapeseed oil that may create autoignition problems when operating with rapeseed oil and jet fuel blends at light engine loads and speeds. A lot of the research and development performed on biofuels using in a diesel engine, however there still is not completely clear what could be the optimal rapeseed oil and jet fuel mixing rate to be recommend for the use in diesel powered transport machines and power generators. Also, there is a lack of 
Table 1. Properties of the tested diesel fuel, rapeseed oil and aviation-turbine JP-8 fuel (NATO code F-34)

\begin{tabular}{|c|c|c|c|c|c|}
\hline Property parameters & Fuel test methods & Jet fuel test methods & Diesel fuel & Rapeseed oil & JP-8 fuel \\
\hline $\begin{array}{l}\text { Density at } 15^{\circ} \mathrm{C} \text {, } \\
\mathrm{kg} / \mathrm{m}^{3}\end{array}$ & EN ISO 12185:1999 & ASTM D 4052-09 & 843 & 916 & 797 \\
\hline $\begin{array}{l}\text { Kinematic } \\
\text { viscosity, } \mathrm{mm}^{2} / \mathrm{s}\end{array}$ & EN ISO $3104+A C: 2000$ at $40^{\circ} \mathrm{C}$ & ASTM D 445 at $-20^{\circ} \mathrm{C}$ & 2.89 & 32.9 & 4.0 \\
\hline $\begin{array}{l}\text { Flash point, open } \\
\text { cup, }{ }^{\circ} \mathrm{C}\end{array}$ & EN ISO 2719:2003 & ASTM D 56-05 & 59 & $220-300$ & 40 \\
\hline $\begin{array}{l}\text { Cold filter plugging } \\
\text { point, }{ }^{\circ} \mathrm{C}\end{array}$ & EN ISO 116/AC:2002 & - & -7 & +15 & -60 \\
\hline Cetane number & \multicolumn{2}{|c|}{ EN 5165:1999 } & 51.3 & $44-48$ & 42.3 \\
\hline $\begin{array}{l}\text { Sulphur total, } \\
\mathrm{mg} / \mathrm{kg}\end{array}$ & EN ISO 20846:2004 & ASTM D 5453-09 & 8.9 & 2 & 9.3 \\
\hline $\begin{array}{l}\text { Iodine number, } \\
\mathrm{J}_{2} \mathrm{~g} / 100 \mathrm{~g}\end{array}$ & EN 14111:2003 & - & 12 & 111 & - \\
\hline $\begin{array}{l}\text { Acid value, } \\
\mathrm{mg} \mathrm{KOH} / \mathrm{g}\end{array}$ & LST EN ISO 660:2000 & ASTM D 3242-11 & 0.06 & 2.0 & 0.001 \\
\hline $\begin{array}{l}\text { Carbon-to-hydro- } \\
\text { gen ratio }(\mathrm{C} / \mathrm{H})\end{array}$ & - & - & 6.5 & 6.5 & 6.1 \\
\hline $\begin{array}{l}\text { Net heating value, } \\
\mathrm{MJ} / \mathrm{kg}\end{array}$ & EN ISO 8217:2007 & ASTM D 4529-01 & 43.1 & 36.87 & 43.23 \\
\hline
\end{tabular}

comprehensive test results concerning changes of various $\mathrm{RO}$ and jet fuel blends' parameters because this alternative fuel intends to be used for diesel engine powering. The use of crude rapeseed oil in older diesel engines would be especially good decision at the agricultural farms where the rapeseed oils cakes owners use for animal breading. In such a case, crude rapeseed oil as a cheap sub-product would be a good alternative to be profitably utilised in agricultural tractors.

\section{The purpose of the research}

The purpose of the research was to study properties of diesel fuel (DF), rapeseed oil (RO), aviation JP-8 fuel and dependency of kinematic viscosity of various rapeseed oil and jet fuel blends RO90, RO80, and RO70 on the amount of jet fuel added (by volumetric percentages) to RO and temperature of the blend. At the next step, there was a goal to perform the laboratory bench tests of a diesel engine operating with alternative fuel blends to measure and compare effective parameters and emissions of the exhaust gases when operating with the above mentioned fuel blends with the ones obtained with pure rapeseed oil, which used as the reference fuel.

\section{The subject and methods of the research}

The subject of the research was diesel fuel, neat rapeseed oil, and various rapeseed oil and jet fuel blends. The research conducted at the Engine test laboratory of Power and transport machinery engineering institute, Engineering faculty of Aleksandras Stulginskis University in the years 2014-2015. For stroke, one cylinder, direct injection, air cooled „ORUVA FL 511” diesel engine was used for these experiments. Technical characteristics of the experimental engine are listed in Table 2. Load characteristics of an engine were taken when operating at gradually increasing load and constant engine speed of $2000 \mathrm{rpm}$ at which an engine maximum torque develops.
The kinematic viscosity of pure rapeseed oil, jet fuel JP-8, and fuel blends RO90, RO80, and RO70 were determined in chemistry laboratory by using capillary viscometer at the temperature of $15,20,40$, and $60^{\circ} \mathrm{C}$.

Engine tests have been conducted by using cold pressed rapeseed oil produced and decanted at Ltd. "Rapsoila" and turbine type jet fuel JP-8 produced at oil refinery plant „Orlen Lietuva“" (Table 1). At first, an engine operated with the normal diesel fuel. Then, the laboratory test were performed with an engine running with pure RO to obtain "baseline" parameters to compare these parameters with those measured when operating with the tested fuel blends. Three mixtures with rapeseed oil (RO) and jet fuel (JP-8) were prepared by mixing in various volumetric ratios $90 \% \mathrm{RO}$ and $10 \% \mathrm{JP}-8$ (RO90), 80\% RO and 20\% JP-8 (RO80) and 70\% RO and $30 \%$ JP-8 (RO70). Finally, the engine operation with these fuel blends was investigated at various loading conditions and constant speed of $2000 \mathrm{rpm}$.

Table 2. Engine FL 511 specifications

\begin{tabular}{|l|c|}
\hline \multicolumn{1}{|c|}{ Type } & Deutz F1L 511 \\
\hline Operating principle & 4 stroke \\
\hline Number of cylinders & one cylinder \\
\hline Bore, $\mathrm{mm}$ & 100 \\
\hline Stroke, mm & 105 \\
\hline Swept volume, $\mathrm{cm}^{3}$ & 825 \\
\hline Compression ratio & 17 \\
\hline Injection timing advance in CADs & $24^{\circ}$ \\
BTDC & $12.8 \pm 5 \%$ \\
\hline Maximum power $(\mathrm{at} 3000 \mathrm{rpm}), \mathrm{kW}$ & 175 \\
\hline Injection $\mathrm{pressure}, \mathrm{bar}$ & $255 \pm 5 \%$ \\
\hline Fuel consumption, $\mathrm{g} / \mathrm{kW} \cdot \mathrm{h}$ & 3000 \\
\hline Rated speed, rpm & 135 \\
\hline Engine weight, $\mathrm{kg}$ & \\
\hline
\end{tabular}


Table 3. The accuracy of the measured engine performance and emission parameters and the uncertainty of the computed experimental results

\begin{tabular}{|l|c|c|}
\hline \multicolumn{1}{|c|}{ Parameter } & Measuring range & Accuracy \\
\hline Torque & $0-60 \mathrm{~N} \cdot \mathrm{m}$ & $\pm 1.5 \%$ \\
\hline Speed & $150-3000 \mathrm{rpm}$ & $\pm 0.5 \%$ \\
\hline $\mathrm{NO}$ & $0-3000 \mathrm{ppm}$ & $5 \%$ \\
\hline $\mathrm{NO}_{2}$ & $0-500 \mathrm{ppm}$ & $5 \%$ \\
\hline $\mathrm{CO}$ & $0-10000 \mathrm{ppm}$ & $5 \%$ \\
\hline $\mathrm{CO}_{2}$ & $0-50 \%$ & $1 \%$ \\
\hline Smoke density & $0-100 \%$ & $1.5 \%$ \\
\hline Engine power output & - & \pm 1 \\
\hline Fuel mass flow rate & - & \pm 0.5 \\
\hline Brake specific fuel consumption & - & \pm 1.5 \\
\hline Brake thermal efficiency & - & \pm 1.5 \\
\hline Air flow rate & - & \pm 1 \\
\hline
\end{tabular}

Torque of an engine was measured with a magnetic powder brake dynamometer PT40M $(0-60 \mathrm{~N} \cdot \mathrm{m})$ with a definition rate of $\pm 0.5 \mathrm{~N} \cdot \mathrm{m}$ and rotation speed with the mechanical tachometer (150-3000 rpm) with an accuracy of $\pm 0.5 \%$ of the measured value. The air mass consumption was measured with the turbine type gas meter CGT-02 (10-100 $\mathrm{m}^{3} / \mathrm{h}$ ) with an accuracy of $\pm 1 \%$ of the measured value, and fuel mass consumption by using electronic scale SK-1000 with an accuracy of $\pm 0.5 \%$.

Emissions of nitric oxide (NO), nitrogen dioxide $\left(\mathrm{NO}_{2}\right)$, carbon monoxide $(\mathrm{CO})$ in parts per million (ppm) and carbon dioxide $\left(\mathrm{CO}_{2}\right)$ in vol\% were measured with electrochemical cells installed in Testo 350 XL flue gas analyser. Total $\mathrm{NO}_{\mathrm{x}}$ emissions were determined as a sum of both $\mathrm{NO}$ and $\mathrm{NO}_{2}$ pollutants with an accuracy of $\pm 5 \mathrm{ppm}$.

Exhaust smoke measured with a Bosch RTT 110 opacity meter with an accuracy of $\pm 0.1 \%$ in a scale range of $0-100 \%$. The measuring rages of apparatus used, accuracies of the measured experimental data of engine performance and exhaust emission parameters and the uncertainties of the calculated test results (power, fuel consumption etc.) are listed in Table 3. To improve reliability of the measured data the tests have been repeated no less than three times.

\section{The test results and analysis}

As Figure 1 shows, as little as $10 \%$ by vol. of jet fuel added to rapeseed oil significantly reduces kinematic viscosity of the fuel blend. This way the kinematic viscosity of rapeseed oil and jet fuel blends RO90, RO80 and RO70 was reduced to 22.1 , 15.9 and $11.2 \mathrm{~mm}^{2} / \mathrm{s}$ at the temperature of $40{ }^{\circ} \mathrm{C}$, whereas that of pure rapeseed oil was equal to 32.9 $\mathrm{mm}^{2} / \mathrm{s}$. Thus, the jet fuel proved itself as a perfect dilution agent and its adding to crude RO in the above given proportions kinematic viscosity of the fuel blends reduced by $32.8,51.7,66.0 \%$. Similar viscosity's changing tendencies remain in value at higher and lower temperatures of the blends.
Despite the fact that the added jet fuel significantly reduced kinematic viscosity of the blends RO90, RO80, and RO70, nevertheless the viscosity still was 7.6, 5.5 and 3.8 times higher compared with that value of $2.89 \mathrm{~mm}^{2} / \mathrm{s}$ of diesel fuel at the temperature of $40{ }^{\circ} \mathrm{C}$. Anyway, the added jet fuel decreased the value of kinematic viscosity of the blends that resulted in better injection and atomisation quality of the fuel. This is especially important because lighter jet fuel droplets evaporate faster than the ones of rapeseed oil and, therefore, more homogeneous the air and fuel mixture will be prepared in the combustion chamber compared to that of a neat rapeseed oil case.

The columns in Fig. 2 present dependencies of brake specific fuel consumption $\left(b_{e}\right)$ on the brake mean effective pressure (bmep) for the tested fuel blends. It can be seen that the minimum be values of $761-320 \mathrm{~g} / \mathrm{kW} \cdot \mathrm{h}$ within all load characteristic range of 0.08 to $0.53 \mathrm{MPa}$ were obtained when operating with the normal diesel fuel and maximum ones - with fuel blend RO90. The brake specific fuel consumption increased for the engine fuelled with rapeseed oil and jet fuel blends at light $(0.08 \mathrm{MPa})$ and medium $(0.30$ $\mathrm{MPa})$ loads compared with the respective values measured with neat rapeseed oil and diesel fuel.

However, fuel economy can be effectively by $2.1 \%$ to $6.1 \%$ improved with regard to that of neat RO by the use of rapeseed oil-jet fuel blends RO90, RO80 and RO70 at full (100\%) engine load and $2000 \mathrm{rpm}$ speed. To be precise, the brake specific fuel consumption gradually decreased with increasing load and reached the minimum value of 313.4 $\mathrm{g} / \mathrm{kW} \cdot \mathrm{h}$ when operating with the most saturated fuel blend RO70 at a high $(0.53 \mathrm{MPa})$ load. When using fuel blend RO70 the bsfc reduced by about $2.0 \%$ compared with that value of $319.9 \mathrm{~g} / \mathrm{kW} \cdot \mathrm{h}$ a straight diesel suggested at the same test conditions.

The obtained test results match well with the findings of many other researchers, who also found that the brake specific consumption is higher when operating with less calorific vegetable oils of various origins compared with

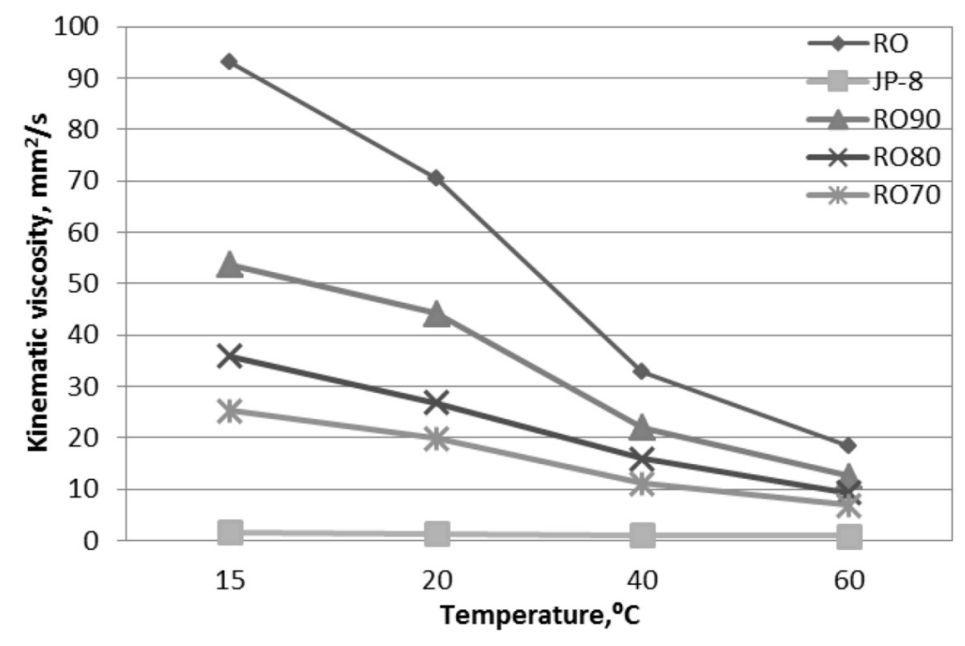

Fig. 1. The impact of the temperature on variations of the kinematic viscosity for various volumetric percentages of jet fuel added to rapeseed oil 


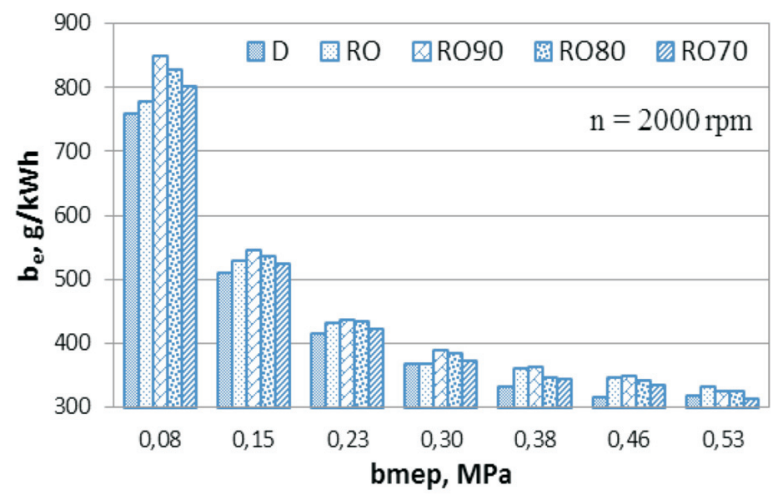

Fig. 2. The impact of the brake mean effective pressure (bmep) on variations of the of brake specific fuel consumption $\left(b_{\mathrm{e}}\right)$ for various $\mathrm{RO}$ and jet fuel blends

the respective values a straight diesel suggests at the same test conditions [14-18].

The brake thermal efficiency $\eta_{\mathrm{e}}$ gradually increased with increasing engine load and reached the maximum value of 0.296 when operating with fuel blend RO70. The obtained efficiency value was about $1.0 \%$ and $13.4 \%$ higher than the respective values of 0.293 and 0.261 measured when operating with neat RO and the normal diesel fuel at full $(0.53 \mathrm{MPa})$ load. Better performance efficiency of an engine powered with fuel blend RO70 can be attributed to faster vaporisation of jet fuel portions and thus higher mixing rate of the air and fuel vapours that resulted in sooner combustion of more homogeneous mixture with lower heat losses to the cooling system.

As columns in Figure 4 show, the amount of total nitrogen $\mathrm{NO}_{\mathrm{x}}$ emissions increased with increasing engine load for all fuels and the fuel blends tested. Replacement of diesel fuel with $\mathrm{RO}$ the maximum $\mathrm{NO}_{\mathrm{x}}$ emission reduced significantly, i.e. from the initial value of $2210 \mathrm{ppm}$ by $11.5 \%$, when operating at full engine load. The amounts of $\mathrm{NO}_{\mathrm{x}}$ emissions produced by the combustion of rapeseed oil and jet fuel blends increased with the increasing volumetric

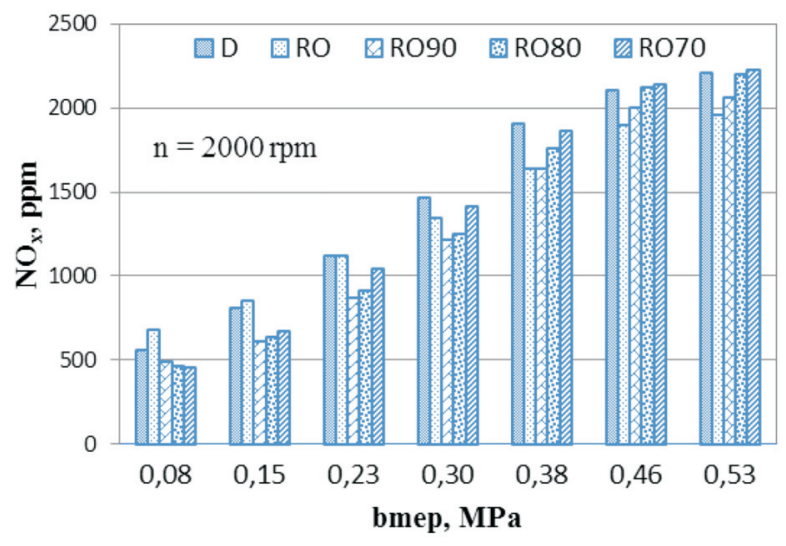

Fig. 4. The dependency of total nitrogen oxides $\mathrm{NO}_{x}$ emissions on engine load (bmep) for various RO and jet fuel blends percentage of jet fuel in the fuel blend for all engine loads tested, except the lowest one of $0.08 \mathrm{MPa}$.

The maximum $\mathrm{NO}_{\mathrm{x}}$ value of $2223 \mathrm{ppm}$ was measured when operating with the most saturated fuel blend RO70 at a high $(0.53 \mathrm{MPa})$ engine load. The obtained $\mathrm{NO}_{\mathrm{x}}$ emission was $13.7 \%$ higher than that (1995 ppm) measured with neat rapeseed oil. Actually, when using fuel blend RO70 the amounts of $\mathrm{NO}_{\mathrm{x}}$ were similar to those a straight diesel produces at full $(100 \%)$ engine load. The increase in nitrogen oxide emissions can be regarded as a normal event because better engine performance efficiency and thus higher gas temperature inside the cylinder usually stimulate the production of $\mathrm{NO}_{\mathrm{x}}$.

Maximum amounts of $\mathrm{CO}$ emissions $(526 \mathrm{ppm})$ produced an engine powered with biofuel blend RO70 and the smallest ones $(231 \mathrm{ppm})$ when operating with neat rapeseed oil at light $(0.08 \mathrm{MPa})$ load. The amounts of $\mathrm{CO}$ emissions

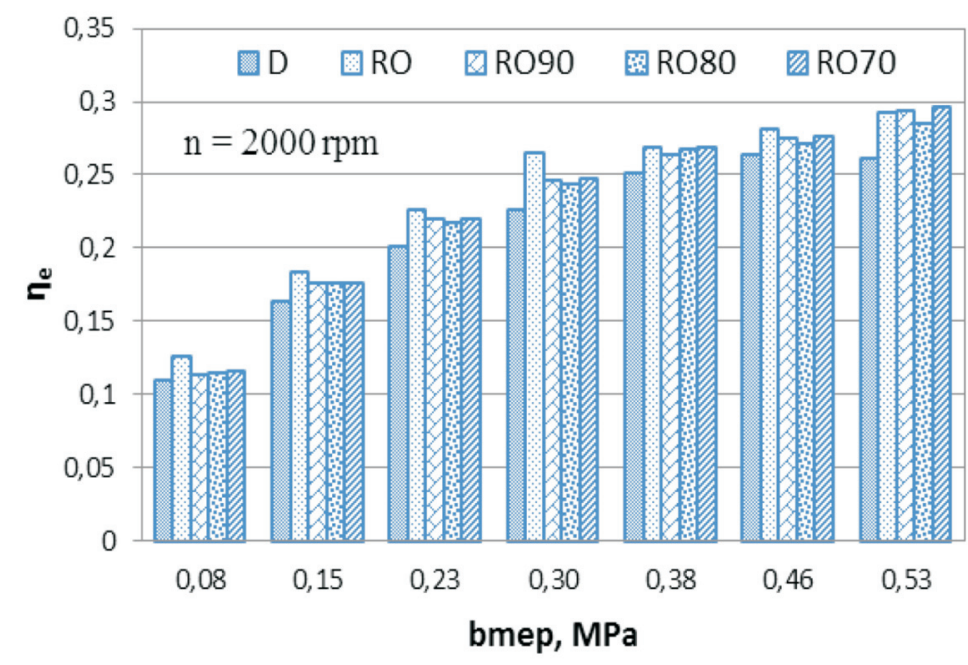

Fig. 3. The dependency of brake thermal efficiency $\left(\eta_{\mathrm{e}}\right)$ on engine load (bmep) for various RO and jet fuel blends

decreased with an increase in engine load and the minimum $\mathrm{CO}$ values were experienced when operating with diesel fuel (155 ppm), slightly higher with neat RO and RO and jet fuel blends at about medium (0.30 MPa) load (Fig. 5). The minimum CO emissions were generated over the whole load range when running with the normal diesel fuel, except a full (100\%) load operation (1636 ppm), and the biggest ones of $1041 \mathrm{ppm}$ when using neat rapeseed oil, again at full $(100 \%)$ engine load.

The amounts of $\mathrm{CO}$ emissions decreased with increasing volumetric percentage of jet fuel in RO blends actually over the entire from $0.15 \mathrm{MPa}$ to $0.53 \mathrm{MPa}$ load range. The $\mathrm{CO}$ emissions decreased by as much as $50.0 \%$ and $68.2 \%$, respectively, when operating with biofuel blend RO70 compared with those values of 1041 and $1636 \mathrm{ppm}$ the combustion of neat rapeseed oil and diesel fuel produces at full (100\%) engine load. The lower $\mathrm{CO}$ (Fig. 5) emitted and less smoke (Fig. 6) produced by the combustion of more concentrated rapeseed oil and jet fuel blends RO80 and RO70 match well 
with the higher $\mathrm{NO}_{\mathrm{x}}$ emissions generated when using these fuel blends (Fig. 4) at the same test conditions.

The amounts of $\mathrm{CO}_{2}$ increased proportionally with increasing bmep due to more fuel consumed to develop the required power output from the crankshaft (Fig. 5). The biggest from 4.1 to $9.9 \mathrm{vol} \% \mathrm{CO}_{2}$ emissions produced a straight diesel within the tested load range of 0.08 to $0.53 \mathrm{MPa}$. A bit lower from 4.1 to $9.0 \%$ amounts of $\mathrm{CO}_{2}$ generated the engine fuelled with ,baseline” neat rapeseed oil. Thus, using of RO and jet fuel blends contributes to production of less $\mathrm{CO}_{2}$ emissions, especially noticeably from 3.8 to $8.9 \%$ by vol. when operating with fuel blend RO70 within the tested load range.

The production of smoke (soot) increased with increasing engine load for all fuels and rapeseed oil and jet fuel blends tested. In a company with the $\mathrm{CO}$ and $\mathrm{CO}_{2}$, the emission of smoke (soot) increased to the highest level of $52.3 \%$ by vol. when operating with the normal diesel fuel at full (100\%) engine load. Both the $\mathrm{CO}$ emitted and the smoke opacity of the exhaust decreased with the increasing volume of jet fuel added to rapeseed oil for all engine loads at speed of $2000 \mathrm{rpm}$.

Better homogeneity of the air and fuel vapours prepared and thus cleaner combustion of the fuel blends RO80 and RO70 resulted in 3.4\% and $19.4 \%$ lover smoke opacity compared with the reference value of $26.3 \%$ produced by the fully $(100 \%)$ loaded engine with a neat rapeseed oil. The obtained effect of using mentioned biofuel blends was even greater, with a reduction of $51.4 \%$ and $59.5 \%$, when compared with the initial value of $52.3 \%$, which the combustion of diesel fuel produces at the same test conditions.

The studies showed that the added jet fuel to rapeseed oil improved operational properties of the fuel blends RO90, RO80, and RO70 and thus performance efficiency of an engine, reduced the $\mathrm{CO}$ emitted, contributed to lower the $\mathrm{CO}_{2}$ emission and smoke (soot) of the exhaust, but slightly increased the $\mathrm{NO}_{x}$ emissions as unavoidable penalty.

\section{Conclusions}

1. Adding of jet fuel to rapeseed oil in 10, 20 and 30\% by vol. proportions the kinematic viscosity of rapeseed oil and jet fuel blends RO90, RO80, and RO70 reduced from the reference value of $32.9 \mathrm{~mm}^{2} / \mathrm{s}$ to $22.1,15.9$, and $11.2 \mathrm{~mm}^{2} / \mathrm{s}$ at the temperature of $40{ }^{\circ} \mathrm{C}$. This measure allowed the kinematic viscosity of the tested fuel blends decrease by $32.8 \%, 51.7 \%$, and $66.0 \%$, respectively.

2. Using of rapeseed oil and jet fuel blend RO70 proved itself as an effective measure to maintain fuel-efficient performance of a DI diesel engine. The brake specific fuel consumption reduced by $6.1 \%$ and $2.0 \%$ reaching $313.4 \mathrm{~g} / \mathrm{kW} \cdot \mathrm{h}$ and brake thermal efficiency increased by nearly $1.0 \%$ and $13.4 \%$ (0.296), respectively, compared with those values a fully $(100 \%)$ loaded engine develops with pure rapeseed oil and diesel fuel at speed of $2000 \mathrm{rpm}$.
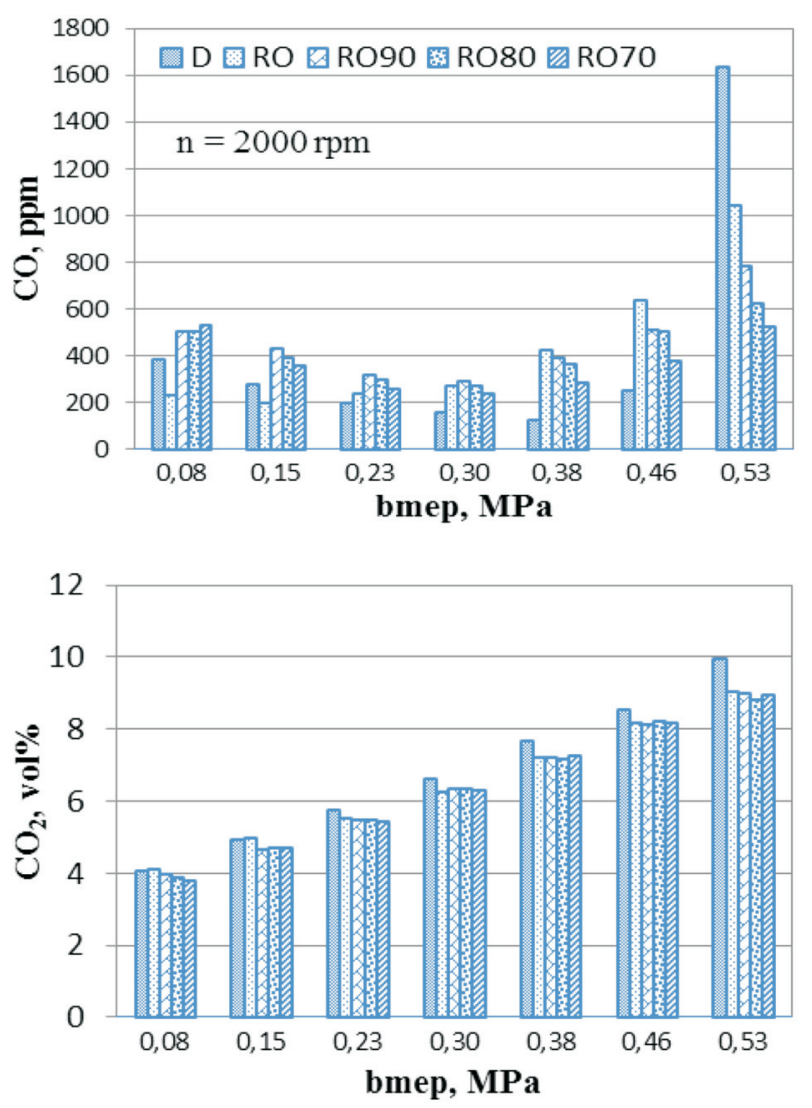

Fig. 5. The dependency of $\mathrm{CO}$ and $\mathrm{CO}_{2}$ emissions on BMEP for various $\mathrm{RO}$ and jet fuel blends

3. The maximum $\mathrm{NO}_{\mathrm{x}}$ emissions increased by $13.7 \%$ when operating with biofuel blend RO70 compared with that value of $1995 \mathrm{ppm}$ measured with neat rapeseed oil and actually sustained at about the same $2223 \mathrm{ppm}$ level as that of $2210 \mathrm{ppm}$ a straight diesel produces at full (100\%) engine load and speed of $2000 \mathrm{rpm}$.

4. The CO emissions decreased by $50.0 \%$ and $68.2 \%$, respectively, when operating with biofuel blend $\mathrm{RO} 70$ compared with those values of 1041 and $1636 \mathrm{ppm}$ the combustion of neat rapeseed oil and diesel fuel produces at full $(100 \%)$ engine load. Whereas the $\mathrm{CO}_{2}$ emission

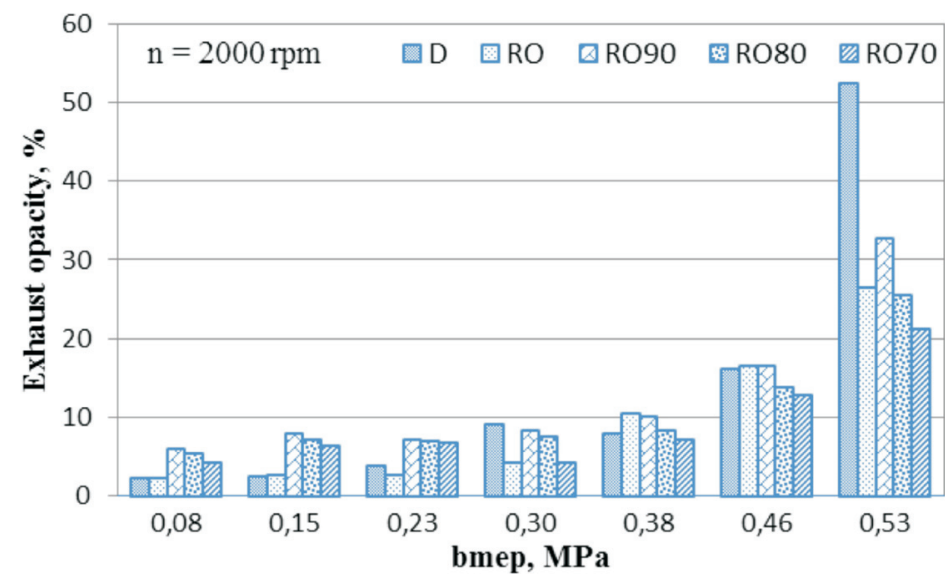

Fig. 6. The dependency of smoke opacity of the exhaust on engine load (bmep) for various RO and jet fuel blends 
changed little with the use of various rapeseed oil and jet fuel blends at given test conditions.

5. Smoke opacity (soot) of the exhaust gases reduced by about $3.4 \%$ and $19.4 \%$ when operating with fuel blends RO80 and RO70 compared with that value of $26.3 \%$ measured with neat rapeseed oil. When fuelled with these fuel blends, the exhaust smoke compiled about as much as a half compared with that value of $52.3 \%$ a normal diesel produces at full (100\%) load and maximum brake torque speed of $2000 \mathrm{rpm}$.

\section{Nomenclature}

RO rapeseed oil

JP-8 aviation-turbine fuel (NATO code F-34)

RO90 90\% rapeseed oil and 10\% JP-8 fuel blend
RO80 $80 \%$ rapeseed oil and 20\% JP-8 fuel blend RO70 $70 \%$ rapeseed oil and 30\% JP-8 fuel blend

\section{Bibliography}

[1] Graboski M.S., McCormick R.L. Combustion of fat and vegetable oil derived fuels in diesel engines. Progress in Energy and Combustion Science, Elsevier, 2 (24), 1998, 125-164.

[2] Peterson C.L., Taberski J.S., Thompson J.C., Chase C.L. The effect of biodiesel feedstock on regulated emissions in chassis dynamometer tests of a pickup truck. Transactions of the ASAE, 6 (43), 2000, 1371-1381.

[3] Dorado M.P., Arnal J.M., Gomez J., Gil A., Lopez F.J. The effect of a waste vegetable oil blend with diesel fuel on engine performance. Transactions of the ASAE, 3 (45), 2002, 519-523.

[4] Lotko W., Lukanin V.N., Khatchiyan A.S. Usage of alternative fuels in internal combustion engines. Moscow: MADI (in Russian), 2000.

[5] Rakopoulos C.D. et al. Comparative performance and emissions study of a direct injection diesel engine using blends of diesel fuel with vegetable oils or bio-diesels of various origins. Energy Conversion and Management, 47, 2006, 3272-3287.

[6] Agarwal D., Agarwal A.K. Performance and emissions characteristics of jatropha oil (preheated and blends) in direct injection compression ignition engine. Applied Thermal Engineering, 27, 2007, 2314-2323.

[7] Luft M. et al. Optimization of injection of pure rape seed oil in modern diesel engines with direct-injection. SAE Technical Paper 2007-01-2031, 2007.

[8] Narayana Reddy J., Ramech A. Parametric studies for improving the performance of a Jatropha oil-fuelled compression ignition engine. Renewable Energy, 31, 2006, 1994-2016.

[9] Agarwal A.K. Biofuels (alcohols and biodiesel) applications as fuels for internal combustion engines. Progress in Energy and Combustion Science, Elsevier, 33, 2007, 233-271.
[10] Murugesan A. et al. Bio-diesel as an alternative fuel for diesel engines - a review. Renewable and Sustainable Energy Reviews, 13, 2009, 653-662.

[11] Labeckas G., Slavinskas S. Comparative performance of direct injection diesel engine operating on ethanol, petrol and rapeseed oil blends. Energy Conversion and Management, 3 (50), 2009, 792-801.

[12] Nygren E., Aleklett K., Höök M. Aviation fuel and future oil production scenarios. Energy Policy, 2009, 4003-4010.

[13] Vilutienè V., Labeckas G., Slavinskas S. Using of alternative fuels in a diesel engine (in Lithuanian). Management Journal of Management, 1 (22), 2013.

[14] McDonnell K.P., Ward S.M., McNulty P.B., Howard-Hildige R. Results of engine and vehicle testing of semirefined rapeseed oil. Transactions of the ASAE, 6 (43), 2000, 1309-1316.

[15] Altin R., Cetinkaya S., Yücesu H.S. The potential of using vegetable oil fuels as fuel for diesel engines. Energy Conversion and Management, 42, 2001, 529-538.

[16] Agarwal A.K., Rajamanoharam K. Experimental investigations of performance and emissions of Karanja oil and its blends in a single cylinder agricultural diesel engine. Applied Energy, 86, 2009, 106-112.

[17] Wang Y.D., Al-Shemmeri T., Eames P. et al. An experimental investigation of the performance and gaseous exhaust emissions of a diesel engine using blends of a vegetable oil. Applied Thermal Engineering, 26, 2006, 1684-1691.

[18] Labeckas G., Slavinskas S. Performance of direct-injection off-road Diesel engine on rapeseed oil. Renewable Energy, 6 (31) 2006, 849-863.
Labeckas Gvidonas, DSc., DEng. - Professor at the Power and Transport Machinery Engineering Institute, Engineering Faculty of Aleksandras Stulginskis University in Kaunas, Lithuania.

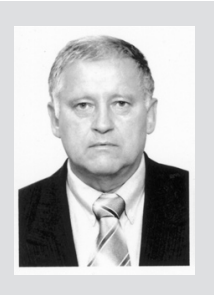

Kanapkiené Irena - PhD student at the Power and Transport Machinery Engineering Institute, Engineering Faculty of Aleksandras Stulginskis University in Kaunas, Lithuania. 